\title{
Biodegradation of sulfamethoxazole by individual and mixed bacteria
}

\author{
Simone Larcher • Viviane Yargeau
}

Received: 8 February 2011 /Revised: 15 March 2011 /Accepted: 16 March 2011 / Published online: 16 April 2011

(C) Springer-Verlag 2011

\begin{abstract}
Antibiotic compounds, like sulfamethoxazole (SMX), have become a concern in the aquatic environment due to the potential development of antibacterial resistances. Due to excretion and disposal, SMX has been frequently detected in wastewaters and surface waters. SMX removal in conventional wastewater treatment plants (WWTPs) ranges from $0 \%$ to $90 \%$, and there are opposing results regarding its biodegradability at lab scale. The objective of this research was to determine the ability of pure cultures of individual and mixed consortia of bacteria (Bacillus subtilis, Pseudomonas aeruginosa, Pseudomonas putida, Rhodococcus equi, Rhodococcus erythropolis, Rhodococcus rhodocrous, and Rhodococcus zopfii) known to exist in WWTP activated sludge to remove SMX. Results showed that $R$. equi alone had the greatest ability to remove SMX leading to $29 \%$ removal (with glucose) and the formation of a metabolite. Degradation pathways and metabolite structures have been proposed based on the potential enzymes produced by $R$. equi. When $R$. equi was mixed with other microorganisms, a positive synergistic effect was not observed and the maximum SMX removal achieved was $5 \%$. This indicates that pure culture results cannot be extrapolated to mixed culture conditions, and the methodology developed here to study the biodegradability of compounds under controlled mixed culture conditions offers an alternative to conven-
\end{abstract}

Electronic supplementary material The online version of this article (doi:10.1007/s00253-011-3257-8) contains supplementary material, which is available to authorized users.

S. Larcher $\cdot$ V. Yargeau $(\bowtie)$

Department of Chemical Engineering, McGill University,

3610 University Street,

Montréal, QC H3A 2B2, Canada

e-mail: viviane.yargeau@mcgill.ca

S. Larcher

e-mail: simone.larcher@mail.mcgill.ca tional studies using pure bacterial cultures or inocula from activated sludge sources consisting of unknown and variable microbial populations.

Keywords Sulfamethoxazole (SMX) - Antibiotics · Biodegradation $\cdot R$. equi $\cdot$ Mixed cultures

\section{Introduction}

The presence of pharmaceutical compounds in the environment has become an increasingly important issue due to their widespread use and disposal worldwide. Antibiotic compounds represent one of the largest concerns as it is believed that their presence will lead to antibacterial resistances in bacteria present in the environment and in biological wastewater treatment (activated sludge) (Andersson 2003; Costanzo et al. 2005; Daughton 2003; Daughton and Ternes 1999; Goni-Urriza et al. 2000; Jorgensen and Halling-Sorensen 2000; Reinthaler et al. 2003; Volkmann et al. 2004).

The estimated antibiotic consumption worldwide ranges from 100,000 to $200,000 \mathrm{t}$ annually, and due to excretion (which can reach up to $90 \%$ of the ingested amount both as the original parent compound or as metabolites) and disposal, up to microgram per liter levels have been detected in raw wastewater (Hirsch et al. 1999; Kümmerer 2009a, b, c; Perez et al. 2005). The synthetic compound sulfamethoxazole (SMX) is one of the most commonly used antibiotics (Cavallucci 2007) and has thus been frequently detected in wastewaters at up to microgram per liter levels and surface waters at nanogram per liter levels (Batt et al. 2007; Benotti et al. 2009; Joss et al. 2005; Kolpin et al. 2002; Miège et al. 2009; Peng et al. 2006; Yargeau et al. 2007). 
SMX removal rates in conventional wastewater treatment plants (WWTPs) have been measured to range from $0 \%$ to $90 \%$ (Carballa et al. 2004; Jones et al. 2005; Miège et al. 2009; Ternes et al. 2006; Xu et al. 2007) with up to an estimated $60 \%$ removal achieved during the activated sludge treatment step (Göbel et al. 2007). At lab scale there have been mixed results regarding the biodegradation of SMX from significant removal in activated sludge (Perez et al. 2005) to minimal biodegradation (Joss et al. 2006). There are also contradictory results regarding the effect of the presence of a more readily degradable carbon source, from an increase of over 30\% SMX removal using the OECD closed-bottle test (Alexy et al. 2004) to no SMX removal with added carbon and nitrogen using a lab-scale sequencing batch reactor (Drillia et al. 2005).

The aim of this research was to determine the ability of pure cultures of individual bacteria that have been found in activated sludge (Benedict and Carlson 1971; Rani et al. 2008; Seviour et al. 2008) as well as controlled mixtures of these pure bacterial cultures to degrade SMX in the presence and absence of a readily degradable carbon source (glucose).

\section{Materials and methods}

\section{Chemicals}

All chemicals used were either reagent grade or HPLC grade. The SMX (CAS 723-46-46), ammonium nitrate $\left(\mathrm{NH}_{4} \mathrm{NO}_{3}\right)$, calcium chloride dihydrate $\left(\mathrm{CaCl}_{2} \cdot 2 \mathrm{H}_{2} \mathrm{O}\right)$, magnesium sulfate heptahydrate $\left(\mathrm{MgSO}_{4} \cdot 7 \mathrm{H}_{2} \mathrm{O}\right)$, and glucose assay kit (GAHK-20) were purchased from Sigma-Aldrich, Canada. The iron sulfate heptahydrate $\left(\mathrm{FeSO}_{4} \cdot 7 \mathrm{H}_{2} \mathrm{O}\right)$, ethylene diamine tetra-acetic acid (EDTA), sodium hydrogen monophosphate $\left(\mathrm{Na}_{2} \mathrm{HPO}_{4}\right)$, sodium dihydrogen phoshate $\left(\mathrm{NaH}_{2} \mathrm{PO}_{4}\right)$, yeast extract, phosphoric acid, and acetonitrile $(\mathrm{ACN})$ were purchased from Fisher Scientific, Canada. The McFarland Standard No. 2 was obtained from Biomérieux, France; the brain heart infusion (BHI) agar was obtained from Becton-Dickinson and Co., Canada; and glucose was obtained from A \& C American Chemicals Ltd., Canada.

\section{Bacteria and cultivation}

The pure bacterial cultures used in this study were obtained from Cedarlane ${ }^{\circledR}$ Canada and stored at $-80{ }^{\circ} \mathrm{C}$ in a glycerol/BHI mixture. Each bacterium was thawed and grown individually in BHI broth for $24 \mathrm{~h}$ in the dark at $26{ }^{\circ} \mathrm{C}$ and $150 \mathrm{rpm}\left(\right.$ INNOVA ${ }^{\circledR} 44$ Incubator Shaker Series) and then plated on BHI agar. After incubation for $24-48 \mathrm{~h}$ at $26^{\circ} \mathrm{C}$ in the dark, the agar plates containing each bacterial growth were stored in the fridge at $4{ }^{\circ} \mathrm{C}$.
The seven bacteria investigated were (ATCC no.): Bacillus subtilis (6051), Pseudomonas aeruginosa (PA01), Pseudomonas putida (12633), Rhodoccocus equi (13557), Rhodoccocus erythropolis (4277), Rhodoccocus rhodocrous (13808), and Rhodoccocus zopfii (51349).

\section{Inhibition tests}

Prior to the mixed bacteria experiments, inhibition tests were conducted to determine if all seven bacteria would grow together successfully. The results of these tests determined the final bacterial mixtures studied.

For each bacterium, the growth on BHI agar plates was used to make cellular standards (McFarland Standard No. 2; $3 \times 10^{8}$ cells $/ \mathrm{mL}$ ) in $6 \mathrm{~mL}$ of a $0.85 \%$ sterile saline solution ( $8.5 \mathrm{~g} / \mathrm{L}$ sodium chloride). Using an automatic micropipet with sterile disposable tips, $100 \mu \mathrm{L}$ of each bacterial standard solution was dispensed onto separate BHI agar plates and then spread evenly using sterile swabs. Sterile filter papers ( $8 \mathrm{~mm}$ diameter) were soaked in the other six individual bacterial standard solutions and placed onto the plates (spaced evenly apart) using sterilized tweezers. The plates were incubated in the dark for $24-48 \mathrm{~h}$ at $26^{\circ} \mathrm{C}$ and visually monitored to determine any bacterial inhibition.

\section{Biodegradation experiments}

Biodegradation experiments were carried out in duplicate using each of the seven bacteria individually and the two bacterial mixtures (groups 1 and 2) determined via inhibition tests and outlined in the "Results" section. Again for each individual bacteria, growth on BHI agar at $26^{\circ} \mathrm{C}$ was used to make cellular standards (McFarland Standard No. $2 ; 3 \times 10^{8}$ cells $/ \mathrm{mL}$ ) in $6 \mathrm{~mL}$ of $0.85 \%$ sterile saline solution. These cellular standards were then used to preinoculate $250-\mathrm{mL}$ Erlenmeyer flasks (working volume of $100 \mathrm{~mL}$ ) containing minimum mineral salt media (MMSM), $6 \mathrm{mg} / \mathrm{L} \mathrm{SMX}$, and $0.5 \mathrm{~g} / \mathrm{L}$ glucose (in the cases considering an easily degradable carbon source) and were placed in a dark incubator shaker $\left(24 \mathrm{~h}, 26{ }^{\circ} \mathrm{C}, 150 \mathrm{rpm}\right)$. This pre-inoculant was prepared in order to acclimate each of the seven bacteria to the test conditions. The MMSM used was composed of $\mathrm{Na}_{2}$ EDTA $2 \mathrm{H}_{2} \mathrm{O}(0.018 \mathrm{~g} / \mathrm{L})$, $\mathrm{FeSO}_{4} \cdot 7 \mathrm{H}_{2} \mathrm{O}(0.013 \mathrm{~g} / \mathrm{L}), \mathrm{CaCl}_{2} \cdot 2 \mathrm{H}_{2} \mathrm{O}(0.013 \mathrm{~g} / \mathrm{L})$, $\mathrm{MgSO}_{4} \cdot 7 \mathrm{H}_{2} \mathrm{O}(0.25 \mathrm{~g} / \mathrm{L}), \mathrm{Na}_{2} \mathrm{HPO}_{4}(7.5 \mathrm{~g} / \mathrm{L}), \mathrm{KH}_{2} \mathrm{PO}_{4}$ $(5 \mathrm{~g} / \mathrm{L}), \mathrm{NH}_{4} \mathrm{NO}_{3}(5 \mathrm{~g} / \mathrm{L})$, and yeast extract $(0.6 \mathrm{~g}$ per liter of the working volume).

For the individual bacteria biodegradation experiments, after $24 \mathrm{~h}$ of growth, $70 \mathrm{~mL}$ of the pre-inoculant was transferred into a 500-mL experimental Erlenmeyer flask (working volume of $350 \mathrm{~mL}$ ); while for the mixed bacteria experiments, equal volumes of each pre-inoculant individual bacterial growth (after $24 \mathrm{~h}$ ) were used to inoculate the 
500-mL experimental Erlenmeyer flask (working volume of $350 \mathrm{~mL}$ ). The total volume of the mixed bacterial preinoculants added to each experimental flask was $70 \mathrm{~mL}$ ( $20 \%$ of the total working volume). It should be noted that although equal volumes of each bacterial preinoculant were mixed together, since each individual bacteria experienced different rates of growth during the $24 \mathrm{~h}$ pre-inoculation, the number of cells per volume was not equal. In order to determine whether this unequal mixing of the bacterial cells had a significant impact on the observed results, additional experiments were carried out in duplicate using bacterial pre-inoculants diluted with sterile MMSM to achieve an identical number of cells in the mixtures tested. The experimental flasks contained the same proportions of MMSM, SMX, and glucose (if necessary) as the pre-inoculant flasks. SMX present in the pre-inoculant flasks was transferred into the experimental flasks during inoculation, explaining the initial SMX concentration that was slightly higher than $6 \mathrm{mg} / \mathrm{L}$.

Control experiments were carried out with the individual and mixed bacteria to verify that any metabolites detected were due solely to SMX transformation. These controls were done by conducting the above-described biodegradation experiments in $\mathrm{MMSM} \pm$ glucose without SMX. Adsorption onto each bacterium was found to be insignificant as indicated by experiments conducted with bacteria killed via autoclaving immediately after pre-inoculation.

\section{Analytical methods}

Bacterial growth was measured via the optical density at $540 \mathrm{~nm}$ using a Thermo Evolution 300 UV-Visible spectrophotometer. For each measurement $3-\mathrm{mL}$ aliquots from the experimental flask were sampled over time using an automatic pipet with sterile tips. Serial dilutions (up to $\left.10^{-8}\right)$ in sterile saline solution $(0.85 \%)$ were also conducted and plated on BHI agar in order to visually confirm the growth (after $24-48 \mathrm{~h}$ incubation at $26{ }^{\circ} \mathrm{C}$ in the dark) of each of the seven strains of bacteria as well as to ensure there was no contamination.

To monitor the concentration of SMX, 2-mL aliquots were removed from each experimental flask over time and centrifuged at $10,000 \mathrm{rpm}$ for $10 \mathrm{~min}$ (Thermo IEC MicroCL 21). One milliliter of the supernantant was then syringe filtered with a $0.22-\mu \mathrm{m}$ PVDF filter directly into an amber vial for HPLC analysis. Determination of SMX was carried out using an Agilent 1200 HPLC equipped with a diode array detector at a wavelength of $273 \mathrm{~nm}$ and an XDB Phenyl column $(150 \times 4.6 \mathrm{~mm}, 3.5 \mu \mathrm{m})$. Mobile phases consisted of $20 \mathrm{mM} \mathrm{NaH} \mathrm{PO}_{4}$ (pH 2.8 using phosphoric acid) and ACN using a gradient from $30 \%$ to $45 \% \mathrm{ACN}$ over $10 \mathrm{~min}$; the method used a column temperature of $40{ }^{\circ} \mathrm{C}$, an injection volume of $10 \mu \mathrm{L}$, and a flow rate of $0.7 \mathrm{~mL} / \mathrm{min}$. The limit of detection and limit of quantification of the HPLC method was 2 and $7 \mu \mathrm{g} / \mathrm{L}$ respectively, while the measurement uncertainty was $2 \%$ (based on the variation of SMX standard measurements).

\section{Results}

Sulfamethoxazole removal by individual bacteria

All seven of the individual bacteria grew in the presence of SMX, therefore there was no inhibition of bacterial growth observed due to exposure to the antibiotic compound. In the presence of glucose, most of the bacteria grew to a maximum optical density measured at $540 \mathrm{~nm}\left(\mathrm{O} \mathrm{D}_{540}\right)$ greater than 1, except $B$. subtilis, which only reached a maximum O.D $D_{540}$ of approximately 0.4 . Both $R$. equi and $R$. zopfii exhibited the greatest growth in the presence of glucose, reaching a maximum O.D $D_{540}$ of approximately 1.3 . In the absence of glucose, the maximum O.D ${ }_{540}$ of most of the bacteria was in the range of $0.5-0.6$, except $B$. subtilis $(0.28)$ and $R$. rhodocrous (0.8). These results are summarized in Table 1 and demonstrate that the presence of glucose resulted in an average increase in bacterial cell density of $114 \%$ (minimum $=54 \%$, maximum $=170 \%$ ). Glucose measurements indicate that after $120 \mathrm{~h}$, there was approximately $1.3-2.2 \%$ of the initial $0.5 \mathrm{~g} / \mathrm{L}$ remaining in solution.

Based on the successful growth of almost all of the bacteria, it was expected that the corresponding SMX removals would be considerable. However, the only significant removal of SMX after $120 \mathrm{~h}$ occurred in the presence of $R$. equi (approximately 15\% without glucose, $29 \%$ with glucose) while the SMX removal achieved by the other six individual bacteria ranged from $0 \%$ to $6.6 \%$. Considering the measurement uncertainty (2\%), the majority of the bacteria were not effective at removing SMX. The growth curves (duplicates for each condition tested) of $R$. equi and corresponding SMX removals are illustrated in Fig. 1a, b, and a summary of all the results of the individual bacteria experiments is outlined in Table 1.

The experiments conducted with $R$. equi resulted in the formation of a metabolite (in the presence of glucose) that was eluted 0.3 min earlier than SMX during HPLC analysis (Fig. 1b); this was also observed to occur in the experiments carried out using $P$. aeruginosa both with and without glucose (Table 1).

Determination of mixed bacterial groups

As described in the "Materials and methods" section, inhibition tests were carried out with all seven individual 
Table 1 Summary of individual bacteria results: maximum growth (optical density measured at $540 \mathrm{~nm}$ ) and SMX percent removal

\begin{tabular}{|c|c|c|c|c|c|}
\hline \multirow[t]{2}{*}{ Bacteria } & \multicolumn{2}{|c|}{ Maximum growth $\left(\mathrm{O}^{\mathrm{D}} \mathrm{D}_{540}\right)^{\mathrm{a}}$} & \multicolumn{2}{|c|}{ SMX percent removal ${ }^{\mathrm{b}}$} & \multirow[t]{2}{*}{ Detection of metabolite } \\
\hline & SMX & SMX+glucose & SMX $(\%)$ & SMX+glucose $(\%)$ & \\
\hline B. subtilis & $\begin{array}{l}0.28 \\
0.24\end{array}$ & $\begin{array}{l}0.43 \\
0.40\end{array}$ & $<1$ & $2.8 \pm 0.03$ & No \\
\hline P. aeruginosa & $\begin{array}{l}0.48 \\
0.47\end{array}$ & $\begin{array}{l}1.07 \\
1.07\end{array}$ & $1.3 \pm 0.15$ & $5.6 \pm 0.15$ & Yes (with and without glucose) \\
\hline P. putida & $\begin{array}{l}0.46 \\
0.46\end{array}$ & $\begin{array}{l}1.25 \\
1.25\end{array}$ & 0 & 0 & No \\
\hline R. equi & $\begin{array}{l}0.64 \\
0.61\end{array}$ & $\begin{array}{l}1.36 \\
1.33\end{array}$ & $15 \pm 1.6$ & $29 \pm 2$ & Yes (with glucose) \\
\hline R. erythropolis & $\begin{array}{l}0.60 \\
0.60\end{array}$ & $\begin{array}{l}1.10 \\
1.00\end{array}$ & $2.9 \pm 0.15$ & $2.6 \pm 0.12$ & No \\
\hline R. rhodocrous & $\begin{array}{l}0.53 \\
0.51\end{array}$ & $\begin{array}{l}1.10 \\
1.03\end{array}$ & $6.6 \pm 0.9$ & $4 \pm 0.2$ & No \\
\hline R. zopfii & $\begin{array}{l}0.53 \\
0.50\end{array}$ & $\begin{array}{l}1.30 \\
1.29\end{array}$ & $<1$ & $<1$ & No \\
\hline
\end{tabular}

${ }^{\text {a }}$ Maxium optical density values measured at $540 \mathrm{~nm}\left(\mathrm{O}_{\mathrm{D}} \mathrm{D}_{540}\right)$ for each duplicate experiment

${ }^{\mathrm{b}}$ Average SMX percent removal of duplicate experiments \pm range in values (after $120 \mathrm{~h}$ )
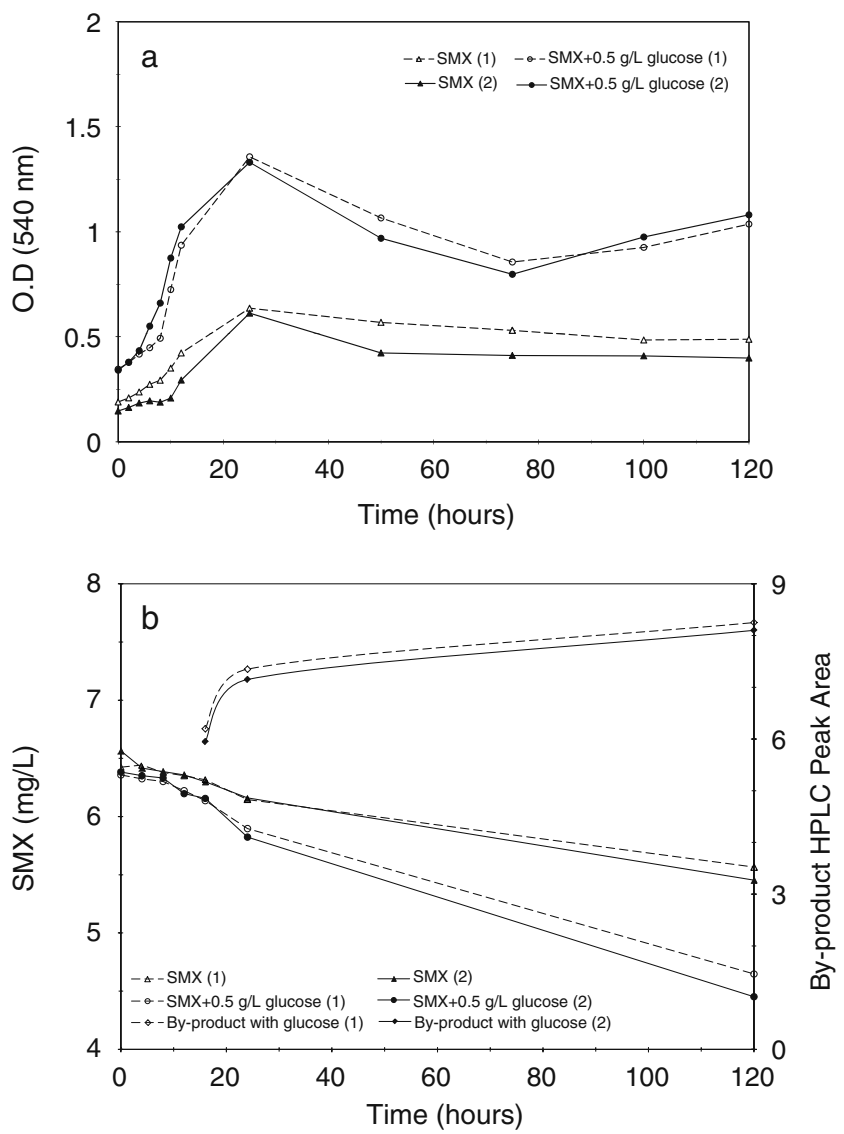

Fig. 1 Biodegradation of sulfamethoxazole $(S M X)$ by $R$. equi with and without glucose in duplicate a bacterial growth; b removal of SMX with time bacteria to determine if they could successfully grow together. Visual observations of the growth of bacteria on the BHI agar plates demonstrated that $P$. aeruginosa inhibited the growth of $B$. subtilis and $R$. zopfii (i.e., on the plates covered evenly with $B$. subtilis and $R$. zopfii, rings of "no growth" were seen around the filter papers soaked in P. aeruginosa standard). Based on the inhibition test results, two different bacterial mixtures were studied. Group 1 consisted of P. aeruginosa, P. putida, R. equi, $R$. erythropolis, and $R$. rhodocrous. Group 2 consisted of $B$. subtilis, P. putida, R. equi, R. erythropolis, R. rhodocrous, and $R$. zopfii.

\section{Sulfamethoxazole removal by bacterial mixtures}

The results of the mixed bacteria experiments are shown in Fig. 2a-d. Figure 2a (group 1) and b (group 2) shows that both bacterial mixtures experienced similar growth reaching a maximum O. $\mathrm{D}_{540}$ of approximately $1.2(\mathrm{SMX}+$ glucose) and 0.65 (SMX alone). This demonstrates the same trend observed with the individual bacteria of increased cell density in the presence of glucose. Similar to the individual bacteria experiments, the initial $0.5 \mathrm{~g} / \mathrm{L}$ glucose was not completely consumed; $7-10 \%$ remained after $120 \mathrm{~h}$, and $1.6-2.2 \%$ remained after $300 \mathrm{~h}$.

In group 1 (Fig. 2c), up to 5\% SMX removal occurred in the presence of glucose and there was also the formation of a metabolite which was eluted at the same retention time during HPLC analysis as the by-product formed during SMX removal by $R$. equi (Fig. 1b) and P. aeruginosa 

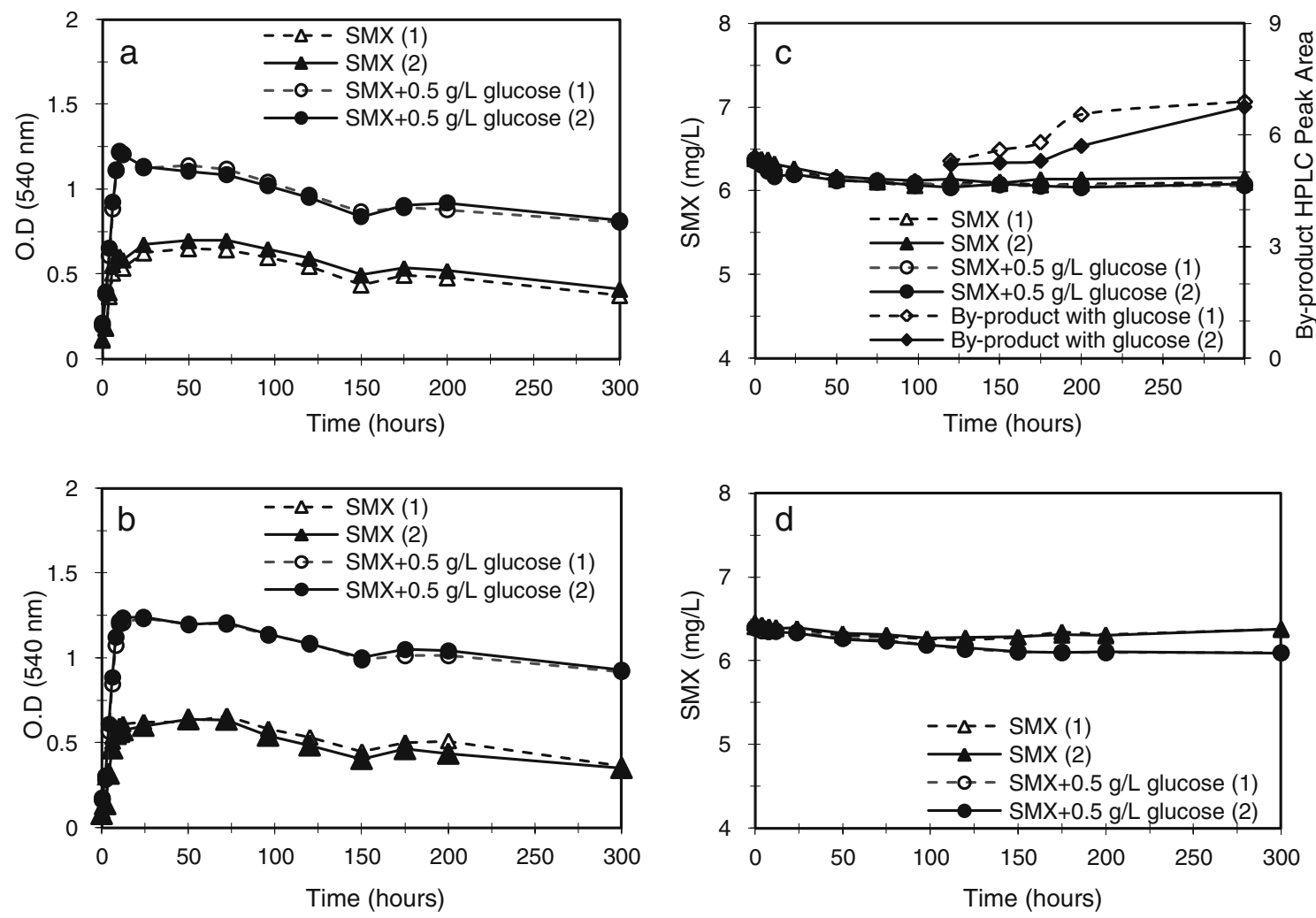

Fig. 2 Biodegradation of sulfamethoxazole $(S M X)$ by mixed bacteria group 1 ( $P$. aeruginosa, $P$. putida, $R$. equi, $R$. erythropolis, and $R$. rhodocrous) and group 2 (B. subtilis, P. putida, R. equi, $R$.

(Table 1). In the absence of glucose, this removal was unchanged but no metabolite was formed. Experiments conducted with MMSM+glucose alone confirmed this metabolite resulted from SMX and not glucose degradation. These results demonstrate that, overall, there was minimal SMX removal via biodegradation (in the absence and presence of glucose) by the mixed bacteria in group 1 .

In group 2 (Fig. 2d), the maximum SMX removal was approximately 5\% (in the presence of glucose); without glucose, the SMX removal was halved. There was no metabolite formation observed with this mixture of bacteria with or without glucose.

$R$. equi, $P$. aeruginosa, and $P$. putida were consistently the fastest growing bacteria during pre-inoculation and therefore were the dominant microorganisms in each mixed group. As discussed previously additional experiments were carried out using bacterial pre-inoculants diluted with sterile MMSM in order to achieve an identical number of cells of the five bacteria in group 1 and the six bacteria in group 2. The results of these experiments (Table 2, Electronic supplementary material) show that diluting the bacterial pre-inoculant growths prior to mixing them did not significantly alter the trends previously observed. The maximum growth (measured via O.D $\mathrm{D}_{540}$ ) achieved by both mixed groups was virtually identical regardless of the pre-

erythropolis, $R$. rhodocrous, and $R$. zopfii) in duplicate. Bacterial growth with and without $0.5 \mathrm{~g} / \mathrm{L}$ glucose a group 1 and $\mathbf{b}$ group 2; removal of SMX with time $\mathbf{c}$ group 1 and $\mathbf{d}$ group 2

inoculant dilution, and in the presence of glucose, the SMX removal was approximately 5\% for both groups 1 and 2 (with the formation of a by-product observed only in undiluted group 1). In the absence of glucose, the dilution slightly lowered the SMX removal observed by $1.6 \%$ (group 1) and $1.1 \%$ (group 2) which is within the uncertainty in measurement $(2 \%)$; therefore, there was essentially no change resulting from pre-inoculant dilution.

\section{Discussion}

Individual bacteria

The results of the SMX degradation experiments carried out using individual bacterial species common to activated sludge (B. subtilis, $P$. aeruginosa, $P$. putida, $R$. equi, $R$. erythropolis, $R$. rhodocrous, and $R$. zopfii) demonstrated that there was only slight SMX removal by six of the seven bacteria studied $(0-6.6 \%$, Table 1$)$. This agrees with previously published results demonstrating that SMX is not readily biodegradable via studies using the OECD closed-bottle, Zahn-Wellens, and $\mathrm{CO}_{2}$ evolution tests (AlAhmad et al. 1999; Gartiser et al. 2007) as well as labscale experiments using inocula from activated sludge 
sources (Joss et al. 2006). R. equi was the only bacteria observed to effectively remove SMX from $15 \%$ up to $29 \%$ with glucose addition (Fig. 1a, b). The presence of glucose not only increased the growth of $R$. equi by $125 \%$, resulting in almost twice as much SMX removal, but also resulted in the formation of a degradation by-product. Although it appears that there is a direct relationship between the presence of glucose leading to increased cell density and SMX removal, further inspection of the results in Table 1 shows that while there was an average 114\% increase in cell density due to the presence of glucose for all the individual bacteria experiments, only three of these resulted in increased SMX removal ( $R$. equi, $P$. aeruginosa, and $B$. subtilis). In addition, $P$. putida exhibited the largest increase in cell density due to the presence of glucose $(170 \%)$, yet there was no detectable SMX removal with or without glucose. Increased bacterial growth in the presence of glucose without a corresponding increase in SMX removal may be a result of these bacteria preferentially consuming this readily degradable carbon source as has been observed to occur in previous research with activated sludge inoculum (Drillia et al. 2005). P. aeruginosa was the only other bacteria whose SMX degradation resulted in the formation of a metabolite both with and without glucose; the $130 \%$ increase in cell density due to glucose resulted in over three times more SMX removal and increased metabolite formation (HPLC peak area doubled). It should be noted that control experiments were conducted as described previously ensuring that the metabolites formed resulted from SMX transformation.

It is known that the genus Rhodococcus consists of bacteria capable of degrading organic compounds that are not easily biodegraded and that bacteria in the genus Pseudomonas can have similar capabilities (Larkin et al. 2005; Martínková et al. 2009). Therefore, the success of $R$. equi and $P$. aeruginosa is not entirely unexpected, but the reasons for their success compared to the other individual bacteria are not clear. It is believed that the degradation of SMX and formation of metabolites are due to the enzymes produced by these bacteria which are not produced to a great extent by the other individual bacteria studied. Using the Enzyme Database BRENDA (BRENDA The Comprehensive Enzyme Information System), the different enzymes produced by the bacteria and their characteristics were determined. It was discovered that arylamine $N$-acetyltransferase is produced by $P$. aeruginosa and Rhodococcus species in general and that this enzyme has a specificity for aromatic amines and can use SMX as a substrate. It is hypothesized that the $R$. equi strain used in this study produced more arylamine $N$-acetyltransferase than any of the other Rhodococcus species tested resulting in higher SMX removal. Although this hypothesis may explain why $R$. equi was the most successful Rhodococcus species, it does not explain why $P$. aeruginosa had less SMX removal (up to $5.6 \%$ ) while still resulting in metabolite formation. This may be due to another enzyme produced by $P$. aeruginosa: dihydropteroate synthetase (DHPS). The antibiotic function of SMX is the competitive inhibition of DHPS, which interrupts the formation of folic acid from 4-amino-benzoic acid in the human body. Since $P$. aeruginosa produces DHPS, it will compete with the arylamine $N$-acetyltransferase that is also being produced, which may have resulted in the observed low SMX removal. While arylamine $N$-acetyltransferase attacks the aromatic amine of SMX producing a by-product, the DHPS binds to SMX. This may account for the detection of a tiny by-product by $P$. aeruginosa even though less SMX removal was observed. The proposed metabolite would have a structure containing an acetyl group attached to the aromatic amine in SMX.

It is also possible that additional enzymes produced by $R$. equi could lead to the hydrolysis of the acetylated SMX by-product. It has been found that a strain of $R$. equi was capable of producing an amidase that degraded lysergamide to lysergic acid (Martínková et al. 2000) and this may have occurred to the acetylated metabolite of SMX to form an alcohol derivative. $R$. equi can also produce urethanase, which hydrolyzes anilides, and $N$-acetyl-phenylethylamine hydrolase which hydrolizes $\mathrm{N}$-acetylated compounds (BRENDA The Comprehensive Enzyme Information System). The increased growth of $R$. equi in the presence of glucose may have lead to the increased production of these enzymes and the formation of an alcohol derivative of the acetylated metabolite. The similarity in structure between the acetylated metabolite and its alcohol derivative would have resulted in similar HPLC elution times, explaining the retention time of the by-products that was 0.3 min earlier than that of SMX. Also, both of these proposed metabolites are more polar than SMX, which would lead to the observed elution earlier than SMX during HPLC analysis. Figure 3 (Electronic supplementary material) illustrates the structure of SMX and the proposed acetylated metabolite and its alcohol derivative.

\section{Mixed bacteria}

As a result of the inhibition tests, the mixed consortia studied consisted of two different groups of bacteria. It was anticipated that the mixed consortia of bacteria might be more successful at degrading SMX as it is commonly thought that synthetic chemicals resistant to degradation by an individual microorganism may be mineralized via complementary transformation reactions due to the participation of more than one microbial species (Janke and Fritsche 1985). However, this expected trend was not 
observed in the mixed bacteria experiments even after $300 \mathrm{~h}$ (Fig. 2c, d). In fact the results demonstrated that $R$. equi alone was more successful (in less than half the time) than either group of mixed bacteria at removing sulfamethoxazole in the presence and absence of glucose. Overall, whether or not equal cellular concentrations of bacterial solutions were combined to form a mixed group of bacteria (Table 2 Electronic supplementary material), the maximum removal of SMX achieved was 5\% after $300 \mathrm{~h}$. This is poor compared to the results of $R$. equi alone, which achieved $5 \%$ SMX removal after only $24 \mathrm{~h}$ and $15 \%$ (without glucose) to $29 \%$ (with glucose) removal after $120 \mathrm{~h}$.

It should be noted that the mixed bacterial group in which a metabolite was detected (group 1) contained both species which produced the metabolite individually (P. aeruginosa and R. equi), whereas group 2, in which no metabolite was detected, only contained $R$. equi. Therefore, it seems that both individual species capable of producing the metabolite were required to be present in the mixtures studied in order for the metabolite to be produced and detected.

These results demonstrate that the ability of an individual bacteria to degrade a compound does not accurately represent what occurs by mixed bacterial cultures, thus a method to study the biodegradation of compounds using controlled mixtures of pure bacterial cultures has been developed. This provides an alternative to the traditional use of inocula from WWTP activated sludge containing unknown and inconsistent microbial communities. The contradictory SMX removals observed at lab scale $(0-80 \%)$ are a result of this inconsistent nature of activated sludge, indicating that the composition of a mixed bacterial culture strongly affects the results obtained. The method proposed in this study using a controlled mixture of pure bacterial cultures provides a laboratory technique to model the biological degradation of compounds that can be precisely repeated. This allows direct comparison of the results of experiments testing varying conditions which is not possible using activated sludge due to the unreliable nature of the microbial population.

Acknowledgments This work was funded by the McGill Engineering Doctoral Award (MEDA), The J.W. McConnell Foundation, the Natural Sciences and Engineering Research Council of Canada (NSERC), and Health Canada.

\section{References}

Al-Ahmad A, Daschner FD, Kümmerer K (1999) Biodegradability of cefotiam, ciprofloxacin, meropenem, penicillin $\mathrm{G}$, and sulfamethoxazole and inhibition of waste water bacteria. Arch Environ Contam Toxicol 37(2):158-163
Alexy R, Kumpel T, Kummerer K (2004) Assessment of degradation of 18 antibiotics in the Closed Bottle Test. Chemosphere 57(6): $505-512$

Andersson DI (2003) Persistence of antibiotic resistant bacteria. Curr Opin Microbiol 6(5):452-456

Batt AL, Kim S, Aga DS (2007) Comparison of the occurrence of antibiotics in four full-scale wastewater treatment plants with varying designs and operations. Chemosphere 68(3):428-435

Benedict RG, Carlson DA (1971) Aerobic heterotrophic bacteria in activated sludge. Water Res 5(11):1023-1030

Benotti MJ, Trenholm RA, Vanderford BJ, Holady JC, Stanford BD, Snyder SA (2009) Pharmaceuticals and endocrine disrupting compounds in U.S. drinking water. Environ Sci Technol 43(3): 597-603. doi:10.1021/es801845a

BRENDA The Comprehensive Enzyme Information System http:// www.brenda-enzymes.org/index.php4. Accessed 27 Feb 2011

Carballa M, Omil F, Lema JM, Llompart M, Garcia-Jares C, Rodriguez I, Gomez M, Ternes T (2004) Behavior of pharmaceuticals, cosmetics and hormones in a sewage treatment plant. Water Res 38(12):2918-2926

Cavallucci S (2007) Top 200: what's topping the charts in prescription drugs this year? Pharmacy Practice, Canadian Healthcare Network. http://www.imshealthcanada.com/vgn/images/portal/ cit_40000873/13/31/8286270612-TOP200-07-final.pdf. Accessed 26 Feb 2008

Costanzo SD, Murby J, Bates J (2005) Ecosystem response to antibiotics entering the aquatic environment. Mar Pollut Bull 51(1-4):218-223

Daughton CG (ed) (2003) Chemicals from pharmaceuticals and personal care products, vol 1. Water: sciences and issues. MacMillan Reference, New York

Daughton CG, Ternes TA (1999) Pharmaceuticals and personal care products in the environment: agents of subtle change? Environ Health Perspect Suppl 107(S6):907-938

Drillia P, Dokianakis SN, Fountoulakis MS, Kornaros M, Stamatelatou $\mathrm{K}$, Lyberatos G (2005) On the occasional biodegradation of pharmaceuticals in the activated sludge process: the example of the antibiotic sulfamethoxazole. J Hazard Mater 122(3):259-265

Gartiser S, Urich E, Alexy R, Kümmerer K (2007) Ultimate biodegradation and elimination of antibiotics in inherent tests. Chemosphere 67(3):604-613

Göbel A, McArdell CS, Joss A, Siegrist H, Giger W (2007) Fate of sulfonamides, macrolides, and trimethoprim in different wastewater treatment technologies. Sci Total Environ 372(2-3):361-371

Goni-Urriza M, Capdepuy M, Arpin C, Raymond N, Caumette P, Quentin C (2000) Impact of an urban effluent on antibiotic resistance of riverine Enterobacteriaceae and Aeromonas spp. Appl Environ Microbiol 66(1):125-132. doi:10.1128/aem.66.1.125132.2000

Hirsch R, Ternes T, Haberer K, Kratz K-L (1999) Occurrence of antibiotics in the aquatic environment. Sci Total Environ 225(1-2):109-118

Janke D, Fritsche W (1985) Nature and significance of microbial cometabolism of xenobiotics. J Basic Microbiol 25(9):603-619

Jones O, Voulvoulis N, Lester JN (2005) Human pharmaceuticals in wastewater treatment processes. Crit Rev Environ Sci Tech 35(4):401-427

Jorgensen SE, Halling-Sorensen B (2000) Drugs in the environment. Chemosphere 40(7):691-699

Joss A, Keller E, Alder AC, Göbel A, McArdell CS, Ternes T, Siegrist $\mathrm{H}$ (2005) Removal of pharmaceuticals and fragrances in biological wastewater treatment. Water Res 39(14):3139-3152

Joss A, Zabczynski S, Gobel A, Hoffmann B, Loffler D, McArdell CS, Ternes TA, Thomsen A, Siegrist H (2006) Biological degradation of pharmaceuticals in municipal wastewater treatment: proposing a classification scheme. Water Res 40(8):1686-1696 
Kolpin DW, Furlong ET, Meyer MT, Thurman EM, Zaugg SD, Barber LB, Buxton HT (2002) Pharmaceuticals, hormones, and other organic wastewater contaminants in U.S. streams, 1999-2000: a national reconnaissance. Environ Sci Technol 36 (6):1202-1211

Kümmerer K (2009a) Antibiotics in the aquatic environment-a review-part I. Chemosphere 75(4):417-434

Kümmerer K (2009b) Antibiotics in the aquatic environment-a review-part II. Chemosphere 75(4):435-441

Kümmerer K (2009c) The presence of pharmaceuticals in the environment due to human use-present knowledge and future challenges. J Environ Manage 90(8):2354-2366

Larkin MJ, Kulakov LA, Allen CCR (2005) Biodegradation and Rhodococcus - masters of catabolic versatility. Curr Opin Biotechnol 16(3):282-290. doi:10.1016/j.copbio.2005.04.007

Martínková L, Kren V, Cvak L, Ovesná M, Prepechalová I (2000) Hydrolysis of lysergamide to lysergic acid by Rhodococcus equi A4. J Biotechnol 84(1):63-66. doi:10.1016/s0168-1656(00) 00332-1

Martínková L, Uhnáková B, Pátek M, Nesvera J, Kren V (2009) Biodegradation potential of the genus Rhodococcus. Environ Int 35(1):162-177. doi:10.1016/j.envint.2008.07.018

Miège C, Choubert JM, Ribeiro L, Eusèbe M, Coquery M (2009) Fate of pharmaceuticals and personal care products in wastewater treatment plants - conception of a database and first results. Environ Pollut 157(5):1721-1726

Peng X, Wang Z, Kuang W, Tan J, Li K (2006) A preliminary study on the occurrence and behavior of sulfonamides, ofloxacin and chloramphenicol antimicrobials in wastewaters of two sewage treatment plants in Guangzhou, China. Sci Total Environ 371(1-3):314-322
Perez S, Eichhorn P, Aga DS (2005) Evaluating the biodegradability of sulfamethazine, sulfamethoxazole, sulfathiazole, and trimethoprim at different stages of sewage treatment. Environ Toxicol Chem 24(6):1361-1367

Rani A, Porwal S, Sharma R, Kapley A, Purohit HJ, Kalia VC (2008) Assessment of microbial diversity in effluent treatment plants by culture dependent and culture independent approaches. Bioresour Technol 99(15):7098-7107

Reinthaler FF, Posch J, Feierl G, Wust G, Haas D, Ruckenbauer G, Mascher F, Marth E (2003) Antibiotic resistance of E. coli in sewage and sludge. Water Res 37(8):1685-1690

Seviour R, Kragelund C, Kong Y, Eales K, Nielsen J, Nielsen P (2008) Ecophysiology of the Actinobacteria in activated sludge systems. Antonie Leeuwenhoek 94(1):21-33

Ternes T, Janex-Habibi M-L, Knacker T, Kreuzinger N, Siegrist H (2006) Assessment of technologies for the removal of pharmaceuticals and personal care products in sewage and drinking water facilities to improve the indirect potable water reuse (POSEIDON Final Report-EU Research Programme) http:// poseidon.bafg.de/servlet/is/2888/. Accessed 1 Feb 2008

Volkmann H, Schwartz T, Bischoff P, Kirchen S, Obst U (2004) Detection of clinically relevant antibiotic-resistance genes in municipal wastewater using real-time PCR (TaqMan). J Microbiol Meth 56(2):277-286

Xu W, Zhang G, Li X, Zou S, Li P, Hu Z, Li J (2007) Occurrence and elimination of antibiotics at four sewage treatment plants in the Pearl River Delta (PRD), South China. Water Res 41(19):45264534

Yargeau V, Lopata A, Metcalfe C (2007) Pharmaceuticals in the Yamaska River, Quebec, Canada. Water Qual Res J Can 42(4): 231-239 